\title{
Ukrainian Philosophical Thought at the Brink between East and West
}

\author{
Pavlo Sodomora
}

Doctor of Philosophical Sciences, Professor, Department of Philosophy, Ivan Franko

National University of Lviv (Lviv, Ukraine)

E-mail: pavlosodom@gmail.com

https://orcid.org/0000-0002-2006-1383

\begin{abstract}
Ukrainian philosophical thought has been developing under the influence of several philosophical streams. Being influences by Orthodox tradition mainly, Church has always been at the forefront of any political campaign conducted on Ukrainian terrain. The level of education plays a key role in the process of cultural development of any country. Western part of Ukraine, comparing to its Eastern counterpart, had better access to education and information due to Catholic Church predominance in the region. Scholastic teaching was accepted by Ukrainian culture partially only, as well as it appeared to be interspersed with Patristics in an Orthodox vestition. The article intends to investigate the scholastic and patristic thought and its reproduction by Ukrainian cultural environment via various European teaching systems. Ukraine has been developing in a broad European context and this is why it could not have been deprived of influential teachings. However, Russian imperialistic and later communist ideology was hindering constantly the deployment and development of many ideas that were important for European philosophy. Together with Eastern theology, which was based mainly on works of Damascenus, Aristotelian traditions were introduced in Ukrainian schools gradually, and based on Aristotle's works, theology of Saint Thomas was taught. Prominent Ukrainian thinkers, such as Petro Mohyla, Kasian Sakovych, Stanislav Orichovsky were influenced by many scholastic philosophers, including Saint Thomas Aquinas. Aquinas' influence is apparent in later thinkers, such as Gabriel Kostelnyk and other prominent philosophers. In conclusion, it is apparent that despite the fact that so-called "philosophy of heart" was more intimate to the majority of Ukrainian thinkers; still Western approach was represented in various aspects and periods of development of Ukrainian philosophical thought.
\end{abstract}

Keywords: education; culture; memory; tradition; translation; being; existence

Received: October 30, 2018; accepted: November 5, 2018

Ukrainian Policymaker, Volume 3, 2018: 65-71.

https://doi.org/10.29202/up/3/9

The question of influence of Western philosophical schools on Ukrainian philosophical thought has been addressed by scholars, but it did not get sufficient attention especially due to scarce facts and sources. There were several works published on the subject [Nichyk, 1990; Kashuba 1990; Zachara et al., 1971] etc, but this question needs deeper investigation as well as

(C) Sodomora, Pavlo, 2018 
it is much deeper than it looks at the first glimpse. Listed works shed some light on philosophy courses that were taught at Kyiv-Mohyla Academy, but the influence of Western thought was not addressed in these works due to political reasons, as Mykola Symchych admits in his article [Symchych, 2012: 148]. The significant gap between Eastern and Western philosophies, cultures, and approaches has always been the subject to controversies. Two main reasons for this can be found in the process or reviewing Ukrainian philosophical thought, as it should be revealed in conclusions. Apparently, there were significant reasons for the word "thomism" to be used with special care in the Soviet period. This is why it has been decided to take a deeper look at the issue. Works of Ukrainian philosophers are investigated here on the subject of presence of Thomistic teaching. In addition to this, the novelty of conducted research is represented by several works of Medieval thinkers that have been recently translated into Ukrainian, such as Saint Augustine [Augustine, 2005], Saint Dionysius [Denise, 2005], Saint Thomas Aquinas [Aquinas, 2010]. The translation of Gabriel Kostelnyk's work "De Principiis Cognotionis" [Kostelnyk, 1913] that is cited here has been completed by the author of the article and awaits for publishing.

The level of education plays a key role in the process of cultural development of any country [Shevchenko 2005]. Uneducated crowd is easier to manipulate than well-educated society, as well as unrealistic fears can be easily implanted into low-educated minds, such as rumors about modern Nazi that are invading from the West as a result of Ukrainian Revolution of Dignity that took place in 2013-2014, or historical facts that are diminished, concealed or even misinterpreted, such as holodomor in Ukraine (1932-1933), or even the fact that radiation emitted by Chernobyl reactor (1986) can be tackled by alcohol consumption. All this misinformation used properly and aided by alcohol helps control the uneducated crowd. On the other hand, it is not that easy to manipulate well-educated people. Historically, Western part of Ukraine, comparing to its Eastern counterpart, had better access to education and information due to Catholic Church predominance in the region [Gudziak, 2000]. This partially explains why there is still "status quo ante" in terms of rivalry between East and WeSaint

Being the main source of education, Orthodox Church has always been at the forefront of any political campaign conducted on Ukrainian terrain [Paslavsky, 2015: 269]. In addition, even in communist times it was in the background of great political changes despite the fact it had been officially separated from the state. Religion was considered to be an important factor in controlling population. Keeping in mind the difference between Eastern and Western rites it is worth looking at some specific aspects of these rites in order to appreciate their particular influence on Ukrainian political and cultural life [Shevchenko, 1996]. The point is that Ukrainian population was susceptible to certain conceptions of Eastern rite, namely to its mystic nature, but also Western rite influenced the Ukrainian culture significantly, particularly due to educational process that had arrived from Europe. Western influence is manifested in Ukrainian academic life, e.g., Kyiv-Mohyla Academy courses and education system. Despite several works in the field, this side of Ukrainian culture has not yet been studied properly due to political reasons, especially due to predominance of Orthodox rite. On the other hand, Eastern influence is represented generally in Ukrainian cultural life, e.g. paintings, architecture and writings.

Beginnings of philosophical thought in Ukraine, as well as its "cultural memory" are linked to Kyiv Rus, especially to baptizing by Constantinople [Kisliuk, 2011: 87] and receiving Christianity, which dates back to $998 \mathrm{AD}$. This event kick-started a big process of adoption of philosophical ideas that had been developed by mainly Christian European philosophers of preceding periods. Ukraine, being like a dry sponge at the time, absorbed what 
had been prepared by the time by European philosophers. And since the philosophy of Plato was predominant in European thought at the time, Ukrainian official philosophy was reluctant to accept newer modifications to philosophy provided by Saint Thomas that were based on philosophy of Aristotle.

Ukrainian cultural and educational life were strongly influenced by scholastic and patristic writings that were both in Latin and Greek. However, scholastic teaching was accepted by Ukrainian culture partially only, as well as it appeared to be interspersed with patristics in an orthodox vestition. The research intends to investigate the scholastic and patristic thought and its reproduction by Ukrainian cultural environment via various European teaching systems. The necessity of investigating the influence of works of scholastic authors on Ukrainian thought is obvious because of significant gap in the field.

The fact that Latin was always dependent on Greek shows common sites of both cultures. There are plenty of words in Latin that are translated directly from Greek, e.g. individuum is translation from Greek atom, accidents is translation from Greek symbebekos etc. This fact approves using copying as one of the methods of specific vocabulary reproducing in Ukrainian writings. For example, Thomas Aquinas uses Latin translations of Greek words widely in his works, but at the same time, he applies entirely Greek words, e.g. hypostasis together with substance. Similar problems are faced in many modern languages, including Ukrainian. The difference between Latin specific words and their modern equivalents is explained on the material of various approaches and in various cultural contexts [Torrel, 1996], including the Ukrainian one [Sodomora: 2009]. The untranslatable words are examined in contrastive bilingual analysis. It is emphasized that in most cases there are no direct equivalents for some words in Ukrainian language.

However, it would be wrong to assume that Western philosophy did not penetrate into Ukrainian Eastern culture. Despite the fact that mainly Byzantine influenced the development of philosophy in universities, Aristotle's philosophy and Aquinas' teaching still were present in a subtle and hidden way in Ukrainian Orthodox schools. In Kyiv-Mohyla Academy, which was the biggest Ukrainian university at the time, materialistic ideas were referred to as a "disease" [Mozhova 2015: 23]. Nevertheless, this was official approach only, because many thinkers viewed Aristotle's philosophy as a reliable and valid answer to many questions and did not associate it with materialism directly. Even nowadays Aristotle's philosophy receives new treatment and approach [Anscombe, 1957]; many scholars are referring to Aristotle's logic from new points of view [Navrotsky, 2016: 27]. Apparently, Aristotle's approach too many questions that were related to being could not have been left without proper attention from many early Ukrainian thinkers.

In fact, Ukraine has been developing in a broad European context and this is why it could not have been deprived of influential teachings. However, Russian imperialistic and later communist ideology was hindering constantly the deployment and development of many ideas that were important for European philosophy. In spite of predominant role of HellenisticBysantine traditions, Western influence could be felt in the educational process of Kyiv-Mohyla Academy [Lyuty, 2017: 72]. Nevertheless, Western influence, which was based mainly on Aristotle and Aquinas, was mostly latent and had never been put on a broad display. Similar situation can be observed on the material of Modern and Post-modern European philosophical thought, e.g. Friedrich Nietzsche, that were opposed to commonly accepted ideology [Lyuty, 2017: 73]. These authors have never been referred to as reliable sources of philosophical thought due to ideological discrepancy from Orthodox, and later Communistic believes. 
The teaching of Saint Thomas was considered to be important source of acquiring knowledge. This is why Cardinal Josyp Slipyj was convinced that Saint Thomas' teaching was important for Ukrainian philosophy and at some point; it even had a "dominating influence" on education [Slipyj 1925: 60] since Kyiv-Mohyla Academy was based on Aquinas' works with "slight Orthodox remodeling". The latter was necessary as well as Catholic teaching was treated with significant precautions in Eastern Ukraine and only due to Union was accepted more gladly in Western Ukraine [Gudziak 2000]. Despite the diversity of two civilizations have collided on Ukrainian terrain, the required foundation was formed in Ukraine for developing its own kind of teaching and culture that combines different approaches, beginning with scholastic and patristic ones. Understanding Ukrainian cultural background and seeing its profound causes is essential in grasping important points of its behavior in modern political life that has been reflecting on whole European community.

Together with Eastern theology, which was based mainly on works of Damascenus, Aristotelian traditions were introduced in Ukrainian schools gradually, and based on Aristotle's works, theology of Saint Thomas was taught. The Metropolitan Velyamyn Rutsky (15741637) considered Saint Thomas' theology to be introduced into Ukrainian schools necessarily [Zachara 2000: 59-60]. Meletius Smotrytsky used "Sententiae" of Peter Lombard in his works. "Sententiae" was central work for theological thought and was studied at European Universities before "Summa" of Saint Thomas appeared. According to Ihor Zachara, despite significant discrepancies between cultural backgrounds of Eastern and Western rites, the soil for scholastic teaching was prepared by that time on Ukrainian terrain.

Consequently, despite the fact that representations of Western schools in Ukrainian philosophy are scarce, still they played an important role in the development of philosophical and theological thought. Prominent Ukrainian thinkers, Kasian Sakovych and Petro Mohyla, while developing their thoughts on human's free will and other concepts, were influenced by many medieval philosophers, including Saint Thomas [Lytvynov 2008: 323]. Although, this influence was not predominant because of modern tendencies in European philosophy that considered human as a creator of personal identity. Stanislav Orichovsky (1513-1566) in developing proofs of God's existence follows Saint Thomas, especially in seeing God as a Primary Cause. However, Thomistic tradition influenced him partially only. Instead, Ukrainian philosopher develops neo-platonic notion of "One" which represents God's unity. Supposedly, this tradition is rooted in Saint Denis' approach to understanding of God's essence. The fact of combining two mainstreams in theology and philosophy, namely Western and Eastern ones, is specific feature of Renaissance Ukrainian thought. This approach served the basis for Brest Union (1595-96), which was one of the most significant events in theological and social life of whole Europe and triggered a chain of crucial political changes. It is apparent that in history of establishing Ukrainian philosophical thought a process of reception of various philosophical conceptions contributed to the development of unique ideas.

One of the most famous places in Aquinas" "Summa Theologiae" is a chapter on proofs of God's existence. Namely, Saint Thomas did not have an intention to prove the God's existence, as well as people basically had already believed in God for about more than 1000 years. Similarly to Stanislav Orichovsky, many scholars developer their thoughts relying on those of Aquinas, and introduced their own views on different subjects at the same time. For instance, Ukrainian thinkers developed their own view on the question of proofs of God's existence. Apparently, professors of Kyiv Mohyla Academy partially follow scholastic tradition and particularly Saint Thomas in providing their own lists of proofs. Stephan Yavorsky provides 
six proofs, Georgij Konysky provides four, but all of them resemble proofs that were provided by Aquinas. Theophan Prokopovych, giving his proofs of God's existence, starts with the proof from motion that is similar to Saint Thomas' approach.

It is essential in this case to emphasize that Prokopovych notices that God can be known only by physical observations. This is the point of view that Aquinas develops in his "Summa's". The approach, in fact, is very different from the Patristic one, especially of Saint Denise the Areopagite, whose theology was more mystical and enigmatic, as well as he was the follower of Plato's philosophy in its newer version. Aquinas, instead, being the follower of Aristotle, rejected nativistic conceptions of Plato's philosophy and introduced into Christian philosophy more realistic principles of Aristotle's approach, that were considered inappropriate and incapable of providing the basics for Christian religion. This is what medieval academic Ukrainian philosophy was combining, joining the official Eastern Orthodox approach with newer views that were floating from the Catholic WeSaint

As observations show, Ukrainian philosophers use the same terminoloigical system as Aquinas uses, but some words are given slightly different meaning. As an instance for this, Stephan Yavorsky provides definition of form and matter, but it differs from its scholastic meaning. According to Stephan Yavorsky, form and matter are equivalent, which is quite opposite to Saint Thomas' understanding of these notions given in "Summa". With the flow of time, western traditions became even stronger, especially in the western part of Ukraine, Halychyna, at the beginning of XX century. One of the followers of Aquinas' teaching was Klementij Hankevych. Especially he was concerned with relation between soul and body, as well as between faith and science, which were the subjects of Aquinas' considerations, as well as it is apparent in "Summa Theologiae".

Gabriel Kostelnyk, quite controversial Ukrainian thinker, argues that both faith and reason are important for adequate understanding and comprehending the world, apparently following Saint Thomas Aquinas. The cognition of essence, according to Saint Thomas, follows the cognition of being, because being is primarily cognizable, and only after cognition of being cognition of "what it is" comes. This feature of Aquinas' philosophy is supported by Gabriel Kostelnyk in Ukrainian philosophical thought. In his article "The Notion of Negation in Human's Cognition" Kostelnyk contrasts being and non-being, arguing that non-being relates to ens rationis. By this Kostelnyk, in fact, supports Aquinas' inferences. Being, according to Kostelnyk, is a basis, upon everything else is based, and everything loses its meaning without it. However, in his works Ukrainian thinker relies on Hume, Kant, and other European thinkers, which allows us to put him on the list of neo-thomists.

In many of his works, Gabriel Kostelnyk addresses various questions on being and its cognition. Namely, in his "On Logical Order" philosopher discusses basics of logical cognition following the principle of independent existence of things from human's consciousness. In addition, as well as this world existed long time before the appearance of human's consciousness, Kostelnyk expresses thought that both faith and reason are necessary for cognition of this world. Apparently, reconciliation of faith and reason is a necessary condition for cognition according to Saint Thomas, too. Kostelnyk argues, that reconciliation of these two opposites does not contradict to religion.

It is known, that one of the most important principles in Aquinas' metaphysics is a principle of limitation of act by potency (or of form by matter), by which philosopher explains, among other issues, the imperfection of human's intellect comparing to God's intellect. Kostelnyk supports this opinion. Relying on Thomas' saying about naturally known principles (Aquinas, 
in its own turn, made this conclusion on the basis of Aristotle's metaphysics), Kostelnyk says that it is, first, impossible to fail about first principles, and second, these principles cannot be proven (indemonstrabiles). While researching on principles of cognition, Kostelnyk cites precise explanation provided by Aquinas on this question: "As well as this principle is whole natural, it can be inferred that it is given to those, who has it, and cannot be obtained via learning. First principles are known from natural light of acting intellect, and cannot be obtained by reasoning, but only because their terms are known". This way of thinking is congruent with Aristotle's words. However, in Kostelnyk's opinion, neither Aristotle, nor Aquinas reach the depth of origin of principles. These thinkers, as Kostelnyk argues, do not analyze the potency, which is the source of principles, but instead opine about principles and argue with those who oppose to their ideas. Because of that neither Aristotle, nor Aquinas, as Kostelnyk notices, do not distinguish sufficiently between objective and subjective necessity of principles.

To say even more about this, while analyzing Aristotle's "Metaphysics" Kostelnyk emphasizes that Aristotle in many places speaks either about principles that constitute thing (e.g. form and matter), or about proving principles, which Kostelnyk defines as "normative principles of cognition" (using Kant's term, although in slightly modified meaning) without specifying the difference between features that belong to the thing properly and distantly. Apparently, Descartes' influence is evident here. Gabriel Kostelnyk was really prominent Ukrainian thinker who developed basic Aquinas' ideas joining them with newer views. He was aware of importance of religion and proper education for the development of nation. Probably this is why Soviet system could not stand killing him. He was assassinated by KGB agents in 1948 in Lviv.

It is worth mentioning that rational philosophy on Ukrainian terrain was developed, among others, by Kazymerzh Twardowski, a prominent Polish philosopher. His approach to philosophy was defined by Brentano's statement that "Vera philosophiae methodus nulla alia nisi scientiae naturalis est", i.e. "The true method of philosophy is not different from other natural scienses" [Karivets 2016: 160]. The source of this statement lies in the philosophy of Aristotle and Thomas Aquinas. These thinkers were compiling their works in strict accordance with logical treminology and were avoiding mysticism and obscure concepts. Kazymerzh Twardowski, being Franz Brentano's student, represented Western tradition, in contrast to Ukrainian philosophers in the Eastern part of Ukraine. Most, if not all of them, were leaning towards Eastern way of thinking, which, being more mystic and irrational, represented mainly Russian traditional approach. Western philosophy was at the forefront of political changes that took place during the development of Ukraine as an independent country.

To conclude, it is apparent that that so-called "philosophy of heart" chiefly represented by Gregory Skovoroda [Chyzevsky 2004] was more intimate to the majority of Ukrainian thinkers than scholasticism of Western thinkers. This could be caused by two causes. The first, the objective, geographical distance and political subjection already aforementioned in the article; and the second, subjective, namely national intimate love to songs and inherent folk traditions [Sodomora: 105-108]. These causes served as a background for development of Ukrainian philosophers. However, despite this fact, Western approach was represented in various aspects and periods of development of Ukrainian philosophical thought. 


\section{References}

Anscombe. Gertrude. Intention. Oxford: Blackwell, 1957.

Aquinas, Thomas. Summa Theologiae. (Translated Pavlo Sodomora). Lviv: Spolom, 2010. [In Ukrainian].

Augustine of Hippo. The City of God. (Translated P. Sodomora). Patriarchat, 4, 2005. [In Ukrainian].

Chyzhevsky, Dmytro. Philosophy of Hryhorij Skovoroda. Kharkiv: Prapor, 2004. [In Ukrainian].

Denise the Areopagite. The Heavenly Hierarchy. (Translated Pavlo Sodomora). Patriarchat, 5, 2005. [In Ukrainian].

Gudziak, Borys. Crisis and Reform: Kyiv Metropoly, Konstantinople’s Patriarchat and Genesis of Brest Union. Lviv, 2000. [In Ukrainian].

Karivets, Ihor. Notes to the Lecture of K. Twardovski "Why Knowledge is Power". Sententiae, 35, 2016: 159-161. [In Ukrainian].

Kashuba, Maria. Konyskyj G. Philosophical Works: In two volumes. Kyiv: Naukova Dumka, 1990. [In Ukrainian].

Kysliuk, Konstiantyn. Ukraine: National and Cultural History. Filosofska Dumka, № 6, 2011. [In Ukrainian].

Kostelnyk, Gabriel. De principiis cognitionis. Lviv: Dila, 1913. [In Latin].

Lytvynov, Volodymyr. Ukraine in Search of its Identity XVI- XVII cent. Kyiv: Naukova Dumka, 2008. [In Ukrainian].

Lyuty, Taras. Ideological Interpretations of Nietzshe's Philosophical Views in the Ukrainian Cultural Context. Sententiae, 36:1, 2017: 71-82.

Mozhova, Natalia. About Sources of Modern Ukrainian Philosophy. Filosofska Dumka. № 3. 2015: 20-23. [In Ukrainian].

Navrotsky, Volodymyr. Aristotle's "Topicon” and Practical Turn in Modern Logics. Filosofska Dumka. № 5. 2016: 27-32. [In Ukrainian].

Nichyk, Valeria. Humanistic and Reformation Ideas in Ukraine. Kyiv: Academy of Sciences, Institute of Philosophy, 1990. [In Ukrainian].

Paslavsky, Ivan. Hysichia and Ratio. Lviv: National Academy of Sciences, 2015. [In Ukrainian]. Ševčenko, Ihor. Ukraine between East and West: Essays on Cultural History to the Early Eighteenth Century. Edmonton - Toronto: Canadian Institute of Ukrainian Studies Press 1996.

Slipyj, Josyp. Saint Thomas Aquinas and Scholastics. Lviv, 1925. [In Ukrainian]

Sodomora, Pavlo. Synonyms and Identity of Denotation: a Problem in the Semiotics of Translation. Semiotics Society proceedings: Legas, New York, 2009: 745-750.

Symchych, Mykola. Translators-Pathfinders: Courses of Philosophy at Kyiv-Mohyla Academy in Translations. Sententiae, 27, 2012: 2. [In Ukrainian].

Torell, Jean. Thomas Aquinas. The Person and his Work. Trans. Robert Royal. Washington: Catholic University of America Press, 1996.

Zakhara, Ihor, Maria Kashuba, and Valeria Nichyk. Philosophy in Kyiv-Mohyla Academy. Filosofska Dumka. № 4, 1971. [In Ukrainian].

Zakhara, Ihor. Ukrainian Academic Philosophy XVII- XVIII cent. Lviv: National University of Lviv, 2000. [In Ukrainian]. 